\title{
Skolt Sámi Heritage, Toivo Immanuel Itkonen (1891-1968), and the Sámi Collections at the National Museum of Finland
}

\author{
Eeva-Kristinna Harlin \& Veli-Pekka lehtola
}

\begin{abstract}
The National Museum of Finland is repatriating their entire Sámi collection to the Sámi museum Siida in Inari. This article illustrates the type of collected material that is to be returned, and what kind of tradition of representation the Sámi museum Siida will have to deal with in the repatriation. A remarkable part of the Sámi collections in the National Museum of Finland has been provided by the well-known Finnish Lappologist, T. I. Itkonen. Due to his many research trips in 1912-1927, altogether 91 per cent of his collections originate from the Skolt Sámi area in the Pechenga region and Kola Peninsula. In exhibitions curated by Itkonen for the National Museum, the Skolt Sámi objects seem to have been relatively well represented, although subjected to the almost compulsory representation of reindeer herding. Because of Itkonen's collection, the repatriation of the whole Sámi collection of the National Museum to the Siida Sámi Museum has an especially poignant meaning for the Skolt Sámi community.
\end{abstract}

Keywords: Skolt Sámi, National Museum of Finland, T. I. Itkonen, Sámi collections, Sámi exhibitions, Siida Sámi Museum.

Many studies have attested that reindeer herding constitutes an essential, and often a stereo-typical, element of Sámi representations in museums, while the diversity of Sámi cultures has often been overlooked (Webb 2006; Silvén 2014). This argument concerns the majority of museums which have followed the ideas of the Lappologist research tradition. A recently strengthened argument is that even the museums owned by the Sámi themselves have favored nomadic Sámi reindeer herding as the dominant image of Sáminess, while the minor Sámi cultures - the Skolt Sámi together with Inari Sámi in Finland - have been underrepresented or unrepresented (e.g. Olsen 2000; Potinkara 2015).

In 2017, the National Museum of Finland decided to repatriate their whole Sámi collection to the Sámi museum Siida in Inari, which is owned and administrated by the Sámi 
themselves. It contains a total of 2,611 inventory numbers, and up to 4,000 Sámi objects, mostly from Finnish Sápmi, constituting the largest ethnographic Sámi object collection in Finland (See Harlin 2019). Thus, this article poses the critical questions: What kind of Sámi collection is being returned to the Sámi, and what kind of prerequisites for representation does the Siida museum offer?

Museums have been powerful forums for distributing images of Sámi culture, which has been exhibited in the National Museum of Finland, beginning already in 1923 when the first Finno-Ugrian exhibition was opened. The Sámi were presented as northern representatives of the large FinnoUgric language family (See Harlin 2019, 49-50). After that, there have been two other exhibitions, and one of them is the focus of this study, which is the tradition of Sámi museum representation in the National Museum of Finland. The Sámi collections are a combination of items from many collectors, but the material provided by $\mathrm{T}$. I. Itkonen constitutes a fifth of the Sámi items, altogether 545 objects at the National Museum.

Toivo Immanuel Itkonen (1891-1968) was a Finnish linguist, ethnographer, and researcher of religion, whose status as an expert on Sámi culture was largely based on the expeditions he made in his youth to Kola Lapland and the Skolt Sámi area, as well as from his extensive research career. The collections of Itkonen, however, have a surprising character compared to the prevailing idea of the dominant nomadic reindeer herding imagery among the Lappologists. Itkonen's collections mostly originate from the Skolt Sámi area in the Peäccam or Pechenga region and Kuâlõk or Kola Peninsula. 91 per cent of his collections are of Skolt Sámi origin. The Skolt Sámi mostly made their living on mixed economies, where small-scale reindeer herding was only one part of their annual cycle.

In this article, we examine Itkonen's emphasis on the Skolt Sámi culture and why he directed his research trips to the east, instead of the west where the Northern Sámi reindeer people lived. We also examine how Itkonen's interests were reflected in the later exhibitions of the National Museum of Finland, especially considering the variety of Sámi groups. The Skolt Sámi collections deserve special attention due to the ongoing repatriation process, since the role and representations of the "minorities of the Sámi minority" in Nordic museums need to be properly addressed. Like museums, researchers also have to translate the provenance of knowledge on the Skolt Sámi cultural heritage into an accessible form. The collections of the National Museum of Finland have been studied in several publications (Schvindt \& Sirelius 1922; Sihvo 1977; Varjola 1982; Härö 1984; Talvio 1993). There is, however, only one master's thesis (Puurunen 2002) that addresses the history and accumulation of the Sámi collections, although they have been the subject of several publications about the material culture of the Sámi (see especially Itkonen 1948 I-II).

As for the material for this article, we use the archives of Itkonen, as well as his accounts of his travels which his son, Terho (also a linguist and professor), later collected into the book Lapin-matkani (My travels to Lapland, 1992). Another main source are the diaries of the National Museum of Finland, where the objects he collected during these travels are recorded (SU 4904, 4922. 4954, 5069 and 5076). Similarly, we use the introductory material connected to the exhibitions in the National Museum of Finland from the 1920s to the 1960s, with photographs taken from 
exhibitions archived in the Picture Archives of the Finnish Heritage Agency.

\section{Collector, Linguist, ETHNOLOGIST}

Toivo Immanuel Itkonen grew up in Inari in Finnish Lapland because his father Lauri moved to Lapland in the 1890s to work as the vicar of Inari where he worked for fourteen years. Many of Toivo's brothers became important "Sámi friends", administrators, and researchers of Lapland - for example, Itkonen's older brother, rural police chief L. I. Itkonen, and his younger brothers, vicar Tuomo Itkonen and professor of linguistics', Erkki Itkonen. Their professions reflect their background as local upper-class Finns, who were in contact with the Sámi in the Inari region. All of them had rudimentary or good skills in Northern Sámi and/or in the Inari Sámi language. In their childhoods, they learned many "a Lapp ways" concerning clothing or knowledge of reindeer herding and fishing (See Itkonen T. 1991:9-19).

Itkonen started his studies of linguistics and ethnography at the University of Helsinki in 1912, when he also made his first linguistic and ethnographic expedition to the Skolt Sámi area. The collections of Sámi objects that Itkonen brought from his expeditions to the National Museum of Finland consisted of hundreds of small objects, as well as complete buildings. In 1916, at the age of 25 , Itkonen published his doctoral thesis in linguistics concerning Eastern Sámi dialects. Apart from linguistic studies, he also published collections of folklore, both from Inari Sámi and Skolt Sámi traditions in 1917 and 1931.

His working career, however, started with his ethnographic studies, as his master's thesis in ethnology was titled Reindeer Herding among Enontekiö Sámi (1916). He became amanuensis in the Archaeological Commisnow the Finnish Heritage Agency) of the University of Helsinki in 1919, working in the ethnographical field. He then became curator of the Seurasaari Open-Air Museum in 1932-35, and director of the ethnographic department of the University of Helsinki in 1935-1955. He was mainly an expert on Sámi material culture, and as a positivist, he believed that only systematic empirical work could produce sufficient cumulative data for making reliable conclusions also in the human sciences. This led him to produce intensive collections of knowledge, similar to the work of J. K. Qvigstad in Norway and K. B. Wiklund in Sweden. Many of Itkonen's views on the development of the Sámi culture were linked with the theories of evolution from his time; this implied that cultures develop hierarchically from more primitive stages to advanced levels. This was the reason for the urgency to collect as much information and material culture as possible, as they believed that cultures were in danger of disappearing. There was also an emphasis on highlighting archaic characteristics of the Sámi culture.

Itkonen also had a diffusionist view of culture, that is, he emphasized the role of cultural loans spreading from "centers" to "peripheries," rather than independent invention, discovery, or innovation by the "marginal cultures" themselves. In this view, the direction of influences could be retraced by comparing the cultural forms of neighboring cultures. The Sámi (or Lapps, as previously called) culture was considered highly interesting for diffusionist researchers because genuine and primeval traces "from the childhood of mankind" could be found among them, as stated by a prominent Finnish ethnologist, Kustaa Vilkuna, a younger colleague of Itkonen (see also Lehtola 2017). 


\section{Eeva-Kristina Harlin \& Veli-Pekka Lehtola}

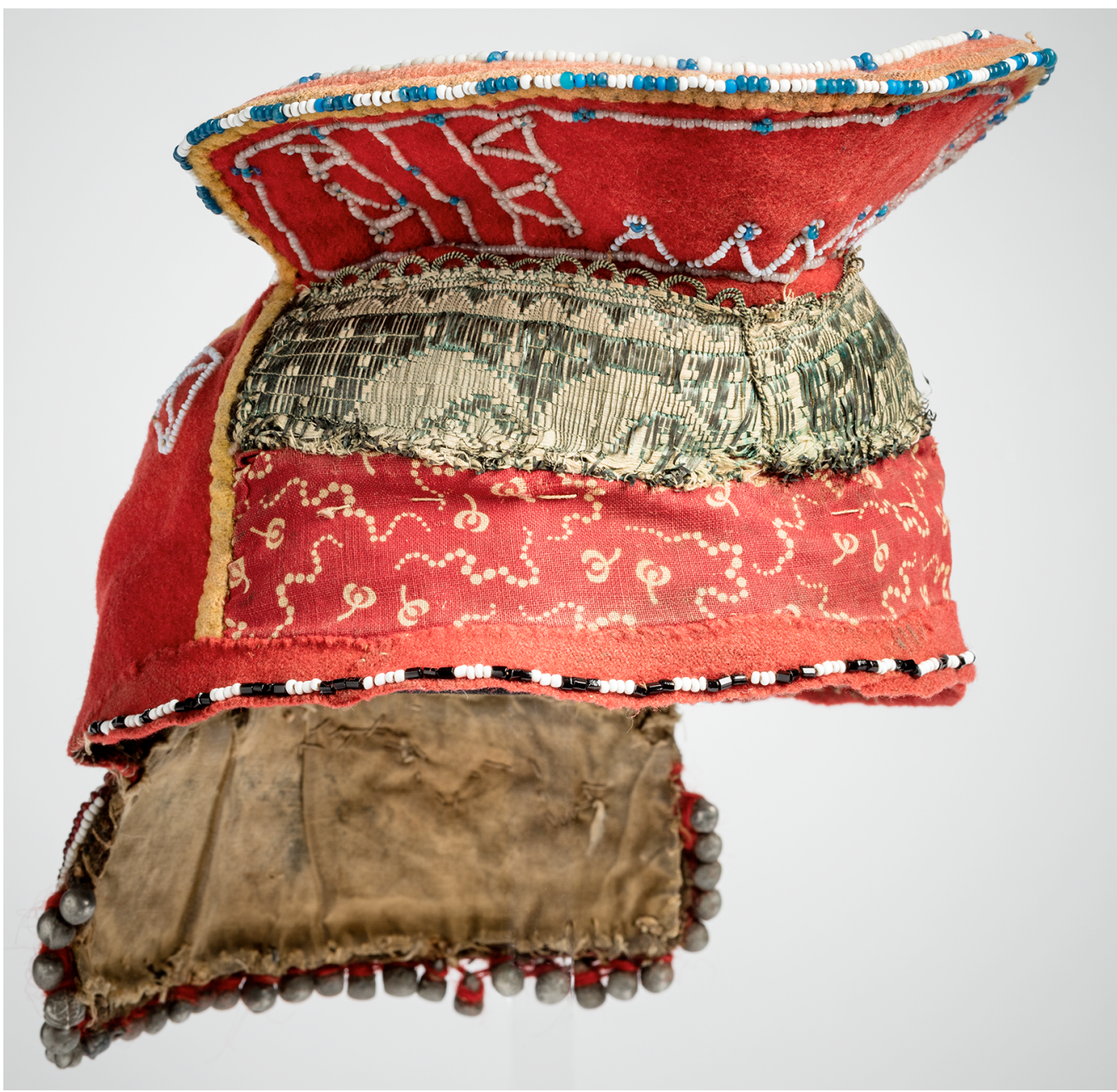

Fig. 1. Saamšik, a hat that is used by married Skolt women. Itkonen purchased this saamši 1912 from Ââlgažjäu'rr. The seller was widow Mosnikoff. Photo: Ilari Järvinen, Antell collections, The National Museum of Finland.

In the 1910s, when Itkonen started his career, Finland was still a part of Russia as the Grand Duchy of Finland. After the independence of Finland in 1917 and the Russian Revolution, the socialist Soviet Russia, later Soviet Union, closed all its borders. In the Tartu Peace Treaty of 1920, the Pechenga region was annexed to Finland, thus Finland acquired a new Sámi group: the Skolt Sámi. Finno-Ugric researchers, who had made earlier expeditions to visit the small Finno-Ugrian peoples in Northern Russia and Siberia, had to turn their fieldwork 
trips toward the north. Especially the Suenjel (Suonikylä) Skolt Sámi area became a popular attraction among Finnish researchers. Along with Samuli Paulaharju, a teacher, collector, and author (Aarekol 2016), Itkonen already had a long acquaintance with the Skolt area.

\section{SAVING A VANISHING CULTURE}

In 1912-1927, T. I. Itkonen pursued a total of six research trips to the Sámi area in Finland and Russia. Most of his trips were to the Skolt Sámi communities, but he also visited the Deatnu (Tana) river valley where the River Sámi population lived; he also visited Enontekiö, the home of the nomadic reindeer Sámi; and Inari, the ancestral lands and waters of the Inari Sámi. Only the reindeer Sámi area of Soabbat (Sompio in Finnish) was left outside of his studies. He got funding or a scholarship from the Finno-Ugrian society ${ }^{1}$ for some journeys $(1912,1913,1926)$ to collect objects for the National Museum and to take ethnographic notes, but also to study the language (Itkonen T. 1991:57; Puurunen 2002:38). Some trips were focused primarily on linguistic studies $(1914,1927)$.

Considering his collections during his first journey, evolutionist theories seem to be involved in Itkonen's interest in relic types of clothing, clothing that was becoming rare and, in most cases, was no longer used. These relics were headgear, e.g. triivik and female outfits or määcca k that had become unfashionable, because most of the Skolt Sámi used a Russian outfit called sarafans. The search for "original" objects was based on the idea that the Skolt Sámi represented the most original stage of the Sámi culture. Itkonen also considered root or birch bark objects, as well as a rare object, a meat vessel made from bark and used on travels, characteristic of Skolt Sámi culture. To record "vanishing knowledge", he attached a detailed description of the process of crafting these objects. The context for collecting items that were about to disappear from everyday use was the ideology that the Skolt Sámi culture was inevitably on the verge of destruction, so it was important to preserve at least part of it.

The comparative method was a means to measure the "originality" of objects. The real ideal of this originality, however, seems to have been based on its "otherness". For a Lappologist, forms of Western civilization were crucial evidence of the degeneration of the "Lapp" culture. He observed, for instance, that the Skolt Sámi did not use antler spoons like the other Sámi, but Russian wooden spoons, which were not considered "genuine" Skolt Sámi objects. Such an "alien influence" was not interesting to him. Itkonen also had a somewhat nostalgic opinion when mentioning that contemporary ornamentation of the Skolts was not as skillfully and nicely done as before, or that some objects, like birch bark "plates," were rare. Other unfortunate outside influences that he mentioned were that Skolt Sámi would carve an orthodox cross in their wooden bowls, vessels, and washing paddle, as well as into children's cradles and bathtubs. The latter, in the form of a sledge or ke'rres, were used by children in the wintertime for tobogganing (SU 4904:30).

Comparing objects was also linked to typology theory that was predominant in Finnish ethnological and archaeological object studies in Finland at the time. When comparing common items of different Sámi groups, such as wooden bowls and vessels, Itkonen made hierarchical conclusions about their developmental stages. He compared different types of chests or keäiss or kijssá or giisá, which the Skolts used as seats; some of them even had a game board painted or carved 
on the lid. He collected a lot of objects that were used for loosening and producing the inner bark of pine for nutrition. These were typical for the forest area from Inari and Skolt Sámi to the Sámi groups in Sweden.

One category Itkonen clearly was interested in were different kinds of bags and pouches, which he meticulously described. He collected some exceptional bags made from bird heads or paddles, and he was very interested in bag mouths of antler and wood. Itkonen pointed out that the bags and mouths that Inari Sámi made were beautiful and well made, in addition to Skolt and mountain Sámi handicrafts (SU 4904:57). He also mentioned that bag mouths were sometimes given as a bridal gift among Skolts. He concluded that since they are made by young people, they are primitive in appearance. Again, Itkonen mentioned that these objects are disappearing.

One can easily see from this collection that Itkonen was extremely focused on handicraft or tuâjj. He was especially interested on techniques and ornamentation. For instance, he collected many distaffs for spinning. These were often given as presents to brides or godmothers; they were valued and beautifully carved (SU 4904:122). It is rather interesting how he was able to buy these objects, since they were considered to be precious by the Skolt Sámi. Interest in ornamentation was typical in the ethnology of Finland and Sweden in those days, and Itkonen gathered many carved objects that were used in handicrafts, in producing fish nets, shoelaces, or needle holsters. He also bought objects that were related to moving and harnessing reindeer, such as storage chests used in travels, a sledge, and a root stitched boat. In each case, he very meticulously described the objects, their preparation techniques, and their usage (SU 4904).

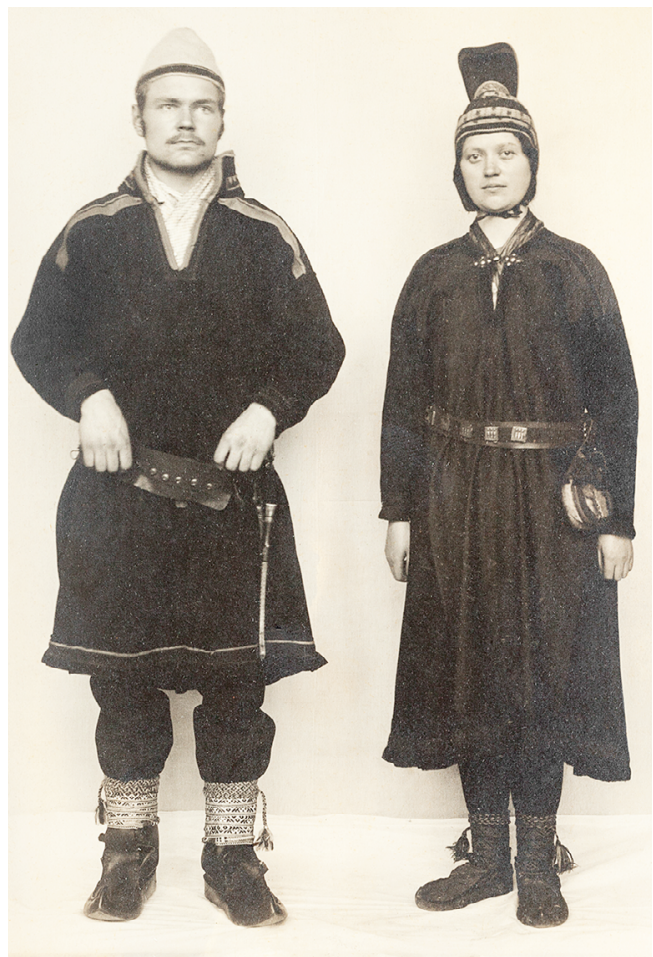

Fig. 2. T.I. Itkonen and Miss Snellman from Muonio pose in Inari Sámi garments. This picture was taken for a museum catalogue in 1914. The museum personnel often posed in the Sámi garments, a rather strange habit from today's museological perspective. Photo: The Finnish Heritage Agency.

The collections of Itkonen from the journey in 1913 (SU 4922) are surprisingly similar to those he collected the previous year. This time, Itkonen also gathered toys and games, like percc, as well as dried food (SU 4922). Collecting duplicates reflects that Sámi objects were valuable as exchange material with other European museums, which was a common practice at that time. In this setting, the Skolt Sámi objects were valued as archaic and exotic items for exchange. For example, Skolt Sámi objects were traded to the National Museum of 


\section{SKolt SÁmi Heritage, ToIvo Immanuel ItKonen (1891-1968), AND THE Sámi Collections at the National Museum of Finland}

Denmark in Copenhagen (SU 4904, 4922). In addition to the Skolt Sámi collection, Itkonen purchased only a limited number of objects from Inari and Enontekiö.

When examining the information about the people behind the collected items, it is rather curious that the first trip he made as a student produced the best documented part of his collections (SU 4904), in addition to the trip in 1926 (SU 5069). From these two trips, the museum diary contains exact descriptions of the use of the objects and their names in the Skolt Sámi or Inari Sámi languages, reflecting the quality of his linguistic skills. The name of the seller was also always mentioned. ${ }^{2}$ During other trips, the lack of information concerning the sellers may reflect the standard of collecting practices at the time. Itkonen may have thought that no future scholars or viewers would be interested in the sellers. Recording the place names that related to the objects seemed much more important, so the development of the collection of items was more associated with the environment, than with the person or the family from which they were purchased. Also at the museum the objects were catalogued and stored in a certain order, which followed the scientific typologies of objects, not their social context, nor the handicraft makers or their families. This emphasized the anonymity of "folk art" or "folk handicraft".

\section{LOCAL GUIDES AND RELUCTANT SELLERS}

During his travels, Itkonen never traveled alone, but had a local guide. Already on his first journey, he hired Inari Sámi Pekka Saijets or Nyere Piäkká (Nuoran-Pekka in Finnish); ${ }^{3}$ he was already an experienced guide, since he had earlier guided e.g. German ethnographers. As a regular guide for Itkonen, Piäkká also assisted greatly with the language, since
Itkonen did not speak Skolt Sámi. When

had their own expressive behavior for fixing the price (Itkonen 1991:57-80; I. Itkonen to T. I. Itkonen 11.5.1912. TIIA. KA.).It was an absolute precondition to have a skillful travel companion, because there were no official roads in the area; Skolt villages were far apart from each other, and the Russian maps were out of date. There were also other reasons for using a local guide. Skolt Sámi people were eager to know who was traveling in their area and for what purpose, but especially people in the inland were still a bit afraid of travelers, as there were various kinds of vagabonds or even deserters on the move. Having a guide was helpful in meeting people, buying objects, or interviewing people, not to mention, getting a place to stay (Itkonen 1991:62, 77).

Itkonen wrote admiringly about Piäkká and his skills in the wilderness. The same applied to Pekka's follower as guide, Uula Morottaja in the 1920s, who later even started to buy objects for the museum independently. Itkonen had also already used Skolt Sámi guides on his first trip, such as Kiureli Moshnikoff, Huotari Moshnikoff and Iivana Feodoroff. He admired Kiureli, for instance, because of his knowledge, his expertise in nature, and his social competence (Itkonen 1991:110-147; Puurunen 2002:38). Even with the moneybag that Itkonen was carrying with him, collecting was not as unproblematic as one would imagine. Itkonen laments: “There were plenty of old objects available, however the Skolt Sámi, especially the elders, were not very eager to sell them." People were reluctant to tell about their old habits and beliefs after such a short acquaintance. According to Itkonen, this sullen characteristic increased toward the inland (Suomalais-Ugrilaisen Seuran vuosikertomus 1912:13-14 in Puurunen 2002:36) 
Itkonen also noticed that the Skolt Sámi were not willing to name the price of the objects, but instead answered by saying, "Jieč tieđak" (you know best), but he did not understand the social norms in such a situation. Despite the "hidden code" he and Nyere Piäkká used to communicate a proper price, not everything was for sale. There were members of the Skolt society, such as an old highly religious man, Ohnas in Källajäurr, who was not at all interested in the visitors or not eager to sell anything (Puurunen 2002:36). According to Itkonen's diary, Iivana Fofonoff in Madsašjaur, for instance, had the most handsome bag mouths, but he would not sell them, not even for five rubles, since they were his father's and grandfather's heirlooms. In Nuortijärvi, Itkonen mentions that everyone traded something, but it required much work, as negotiations about prices took time and demanded bargaining. Julius Konietzko, who collected objects for the museums of Hamburg and Berlin, was even thrown out of a storage in Sulkusjärvi by the energetic matron of the house (Itkonen, T.I. 1991:60-66, 97-98; SU 4904:57).

Other collectors complained about similar difficulties. In 1919, Eliel Lagercranz noted in Karesuando that Ossian Elgström, a Swedish artist, had bought a lot of objects so that there were not many interesting items remaining to be purchased. According to Lagercranz, the Sámi put "senseless prices [...] on useless things" and that the quality of the ornamentation is "the poorest". In his report to the National Museum, he complained that the Karesuando Sámi had been "spoiled" in Norway by tourists and they were "tearing high prices" (Lagercranz, E. 1919, 1931). Also, Ilmari Itkonen, Toivo Immanuel's brother, wrote to the director of the National Museum in 1910 that all "scrap" costs money and nothing is free. He also commented that antler objects have been so popular for collectors and buyers that they are vanishing or, if they are made at all, they are "inferior". Among Inari Sámi, it was impossible to buy silver objects, as well as belts and spoons, because they were expensive and rare. There were rings, but even though the decorative leaflets were broken, sellers demanded the whole price (Itkonen, I. 1910).

Thus, there were many collectors "on the road". For some Sámi, this could be a good opportunity to trade and make money, even to the extent of selling all of their available items. Other Sámi people were not always as willing to sell their wares, and they probably often experienced the situation as awkward. The visitors rushed to the stocks and sheds in order to dig out the valuable objects. Some people probably did not tolerate it, while some indicated their feelings about the traders by selling their items for high prices. One can assume that many Sámi did not consider these kinds of trading practices honest and equal, but they often felt pressure to sell their items, and maybe sometimes they got fed up of the persistent collectors (see e.g. Lonetree 2012).

\section{EXHIBITIONS CREATING IMAGERIES}

During the twentieth century, there were three Sámi exhibitions in the National Museum of Finland, inaugurated in 1923, 1948, and 1974, as part of a larger Finno-Ugric exhibition; the fourth exhibition was displayed in 2000-2017. Currently there is no Sámi exhibition at the National Museum of Finland, as Sámi history is presented, though in a minor scale, as part of the centenniel celebration of Finland's independence exhibition. It is clear that the National Museum had an important role in creating representations of the Sámi or "Lapp" culture for the Finns, since it had millions of 


\section{SKolt Sámi Heritage, ToIvo Immanuel ItKonen (1891-1968), AND THE Sámi Collections at the National Museum of Finland}

visitors over the century. Countless school children visited the museum, and for many generations, the Sámi exhibition was the only knowledge they received about the Sámi people, therefore it is only fair to say, that this presentation became very influential in Finland.

The first Sámi exhibition in the National Museum of Finland was opened in 1923 as part of a larger Finno-Ugrian exhibition. The general atmosphere was favorable for such an exhibition, as Finnish scholars, and even politicians, emphasized that Finland was one of the leading "advanced" nations among the Finno-Ugrian peoples. One trait in the exhibition was also to highlight the Finnish culture to the detriment of the Swedish minority in Finland, who were represented in a subsidiary role (Talvio 2016:186, 189, 235-237). The Finno-Ugrian exhibition was mainly designed by intendant U.T. Sirelius, who was also the first professor of FinnoUgrian Ethnology at the University of Helsinki and a "mentor" to Itkonen, who produced the exhibition as his assistant curator together with Tyyni Vahter. The whole exhibition consisted of six rooms, with the exhibition on Sámi culture taking place in its own room (Suomen Kansallismuseo 1933:67-68, 71-72, 75).

In a guidebook written ten years later in 1933, the Sámi culture, along with other "nomad cultures," was presented as belonging to the most primitive level of the Finno-Ugric language group. According to the guidebook, the Sámi did not racially belong to the FinnoUgrian family, but after having lived alongside neighboring peoples, they had forgotten their own language and adopted a new one. The leaflet reflects the material culture and living conditions of the Sámi as primitive, such as herding, hunting, and fishing (Suomen Kansallismuseo 1933:67, 71-72). The meaning of this interpretation seems to be that rather than depicting Sámi cultures in a rational way, they chose to distinguish them from Finnish people as the zeit geist required. Old guidebooks and picture material reveal that the exhibition aimed to introduce the whole scale of Sámi life through objects the Sámi had produced and used, for example in their livelihoods of hunting and fishing. Furthermore, there was a large presentation of equipment for preparing and eating food, like wooden bowls and containers. Storage items made of roots and birch bark, Sámi coffins made of wood, and smaller objects for storing female utensils were also introduced.

Several genuine looking mannequins represented all the Sámi groups in Finland. These mannequins were made by an artist ${ }^{4}$ to look as Sámi as possible, that is, to represent the Sámi "race" and appearance. ${ }^{5}$ On the wall behind them, other items were displayed, like belts, woolen cloths, headgear, reindeer harnesses, bags, and pouches. Some of the mannequins represented children, and childhood was depicted with Sámi cradles and toys, as well as a Skolt-Sámi bathtub for babies made from wood. Handicrafts had a central role, with many different objects; in addition, jewelry and accessories as well as religious objects, both contemporary and historical, were presented. The centerpiece in the exhibition was a harnessed reindeer from the Enontekiö area. This was a typical and fashionable "Lappish" equipage that was a popular way of presenting Sámi culture in museums at the time (Mathisen 2017:58). Many of the objects, such as a sledge, were related to reindeer, its harnessing, and using reindeer as a draught animal. As a curiosity, food was exhibited usually in a dried form, for example reindeer tongues and fat, as well as blood stored in a reindeer stomach (See also Baglo, in this volume.). 
54 The Sámi exhibition displayed a great number of objects to the visitors in rather small localities. The walls and vitrines were full of Sámi objects, reflecting the rich variety of the collections. Yet the information in the leaflet was not very informative, since the use of the objects, for instance, was described only briefly, if at all. Today, the grouping of the objects seems a bit strange, as in some cases it is difficult to perceive why some objects were presented together. Sometimes the rallying point was the material the objects were made of, sometimes the context they were used in, and sometimes a scientific typology.

Already the first exhibition, which lasted up to the Winter War (1939-40), seems to have created a popular "story of Lappish culture". From then on, the exhibited themes, and even objects, started to stabilize as the core aspects of Sámi representation, also in later exhibitions. Although the whole collection of the National Museum contained over 2,600 items, the same objects seem to have been displayed through all exhibitions in the twentieth century (See Harlin 2018:49-50). This was an interesting way to combine the "otherness" of the Sámi culture into a certain familiarity for the visitors who were taught to know what to expect in the exhibitions.

The same could be seen in the new exhibition, which was opened in 1948, after WWII. This time the exhibition was curated by Itkonen as the department manager and Vahter as the intendant. It was also given much more space; out of the eight rooms of the whole exhibition, Sámi cultures were displayed in three rooms (Talvio 2016:186, 189, 235-257). The new exhibition presented Sámi culture in a more systematic way, and dealt with different themes: carriers and vehicles, dresses and household items, livelihoods, technology and beliefs. The division reflected the themes in Itkonen's book, Suomen lappalaiset I-II (Lapps of Finland), a huge, even encyclopedic, project on "everything concerning the Sámi". The variety of the different Sámi groups was presented, but there was no written information to reveal the methods. Itkonen and Vahter used the whole Sámi collection of the museum, and the exact amount of Skolt objects is difficult to determine; there was no written information about the exact objects that were used in the first two Sámi exhibitions. ${ }^{6}$ When the guests arrived in the exhibition, they met the "Lappish" equipage, a harnessed reindeer as a draught animal, carrying open Sámi chests (giisas) on both sides. As a complement, different kinds of Sámi sledges and several Sámi storage chests were hanging on the wall. This way, the mobility of the (reindeer herding) Sámi culture was highlighted. There were parts of harnesses, skis, reindeer hides used in travels and different kinds of carriers used like rucksacks, but also bags and a rosna, a special backpack or carrying object used by the Skolt Sámi (Kansallismuseo 1966, 605:1-4).

According to the guidebook, "the most primitive" clothing is used in winter, such as čehporas, a bear or wolverine fur collar used by men in earlier times. Also woven wool clothes, produced by Skolt and Utsjoki Sámi, were displayed. All kinds of household items were described according to their material, such as birch bark, wood, antler, leather, and root; these traditions were known in other Sámi areas, too, for example in the Sodankylä area, but they are still practiced only among the Skolt, Lule and South Sámi today. There was also a presentation of objects used for loosening the inner bark of pine for nutrition, which was especially practiced in the forest area by the Inari Sámi, Skolt Sámi and Sámi from the Swedish side of Sápmi. Items related to reindeer milking, like the milking vessel 


\section{SKolt SÁmi Heritage, ToIvo Immanuel ItKonen (1891-1968), AND THE}

Sámi Collections at the National Museum of Finland

náhpi, milk sieve, containers, cheese molds and a cheese dryer also presented the livelihoods.

Highlights of the exhibition were the same mannequins that were used in earlier exhibitions. There was summer and winter clothing from Utsjoki, Inari, and the Vuotso area in the other vitrines. Mannequins were for example dressed up as a Sámi family from Utsjoki, wearing winter clothes. In addition, a girl from Utsjoki and an Inari Sámi man were dressed in summer outfits. Some of the clothing, like the bear or wolverine fur collar, čehporas and the horn hat, ládjogahpir had already gone out of use when the exhibition was made For example, the njálfahtta, a poncho-like garment used by women, was no longer used on the Finnish side of Sápmi, but is still used today in the Julev Sámi area. Many items connected to clothing, dried food, bags, and ornaments, which were the same as in the former exhibition (Kansallismuseo 1966:605:5-11).

The last room presented reindeer herding, while fishing and hunting were briefly mentioned not to mention farming. Thus, the presentation focused on characteristics of Sámi cultures that differed from Finnish culture and livelihoods. Again, handicrafts were discussed, especially how the Skolt women still used spindle and distaff and how they made fine woolen clothes with a "primitive" standing loom. Differences in female and male work and missions were discussed in the guidebook. A vitrine displayed a mannequin dressed as a Skolt man and a wife in winter outfits, and there was also a girl dressed in a Skolt Sámi summer dress. Three vitrines presented objects related to religion, including bibles and some excavated material from Sámi burial sites. One glass case was filled with toys and games (Kansallismuseo 1966: 11-21). It seems that the reindeer Sámi and Skolt Sámi were often presented in the exhibition, while the material culture of the Inari Sámi remained nearly imperceptible (cf. Baglo, in this volume). In the guidebook, the Sámi material culture was described as simplistic, but did reflect artistic skills. Reindeer were considered invaluable, because they could be utilized in so many ways (Talvio 2016:186, 189, 235-7.)

This storyline turned out to be long lasting, because the new exhibition was not opened until in 1974. The third exhibition lasted until the end of the twentieth century, displaying 183 objects and it also introduced "Lappish" equipage and garments from different Sámi groups on eight full-sized mannequins. The pre-Christian Sámi religion was now highlighted with a historical drum of a Sámi noaidi or "shaman," although not from the Finnish area, but from the Southern Sámi area in Sweden. The drum was on loan from the the Nordiska Museet in Stockholm, and the museum had only one drum from the Finnsh side of Sápmi in their collections. That drum was a lot bigger and very rare, as there are only two such drums in existence today.

In the year 2000, the Sámi exhibition of the National Museum of Finland returned to its roots - now the Sámi culture was again displayed in only one room with a vast number of objects, 248 items altogether. It was based on the old collections of the museum, which emphasized the traditional nature of Sámi society. The modern Sámi culture was represented with a video from a reindeer corral in 1999 (see Harlin 2019:50). Thus, the rather old-fashioned, one-sided and exotic representations of the Sámi remained stable, although the world within the Sámi area was undergoing dramatic change after World War II (see Lehtola 2015). For many leading Lappologists during the post-war years, it was difficult to accept that the 
"genuine” Sámi culture was vanishing. Authors and photographers, such as school inspector Antti Hämäläinen, wanted to maintain and distribute their images of the pre-war time, even if they saw the modernization of Lapland which made the images old-fashioned (Lehtola 2017).

In 1949, Itkonen also traveled to Inari and Utsjoki with his family. The land he had been familiar with during his travels was no longer the same. The childhood landscape had vanished as his old home village of Inari had been burned to the ground during the war. The border now divided the traditional areas of the Skolt Sámi, who had been resettled to new areas on the Finnish side of the border. According to his son Terho, the Sápmi that Itkonen had grown to know and admire no longer existed. Therefore, he never returned to Sápmi, except in his memories (Itkonen, T. 1991:19).

\section{Conclusion}

In his collecting practices, Itkonen mostly focused on the Skolt Sámi and only partly on other Sámi groups, although he made his master's thesis on nomadic reindeer herding. Thus, the dominant part of Itkonen's Sámi collections in the National Museum of Finland was of Skolt Sámi origin. You can also see that in the exhibitions of the National Museum, the Skolt Sámi objects were well represented, although the source material does not give details for evaluation of the content. When the collection of the National Museum of Finland - gathered, studied, and presented in so many ways - is repatriated to Sápmi, it will receive a momentous task. For the Skolt Sámi, who have an especially difficult history with many forced diasporas from their own homelands, the repatriation has a specific significance in mediating the traditional knowledge and spirit of the ancestors. Skolt Sámi activist Pauliina Feodoroff states:

In Skolt Saami context, I think the need is even more vital since we have no access to the ancestral lands, not even to our ancestors' old dwelling sites or storages, where we could find an ancient wife's headdress worn by a great-great-grandmother, as families that have stayed in their areas for a long period of time can do. My people were left without an inheritance from where to form a living bridge between ancient and contemporary design. We, who have been born in exile, don't know how the Skolt Saami world looked like as a whole, what our people considered beautiful and harmonious. The whole legacy is in a handful of objects in our families (Pauliina Feodoroff 2019).

Considering the central role of the Skolt Sámi in the early collections of the National Museum of Finland, one can wonder how this role later changed so radically. It is clear that even in the permanent exhibition (1998-2022) of the Siida Sámi museum, for instance, the imperceptible role of the Skolt Sámi and Inari Sámi cultures have been obvious, reflecting the discrepancy between the prevailing representation of the North Sámi cultures and the minor Sámi groups. The interesting questions therefore are: If the Skolt Sámi were emphasized in the collections and works of Itkonen, how did this diversity diminish later, and how did the Skolt Sámi remain only a historical relic in the exhibitions?

The main reason for Itkonen's interest in Skolt Sámi culture was his motivation to study eastern Sámi languages. As a polymorphous scholar, however, he combined ethnologist, folkloristic, and linguistic practices on every trip. His field trips in 1912-1927 reflected his background as a person who had grown up in the Sámi area, which could be seen, for example, in his use of the services of local Sámi guides. 


\section{SKolt SÁmi Heritage, ToIvo Immanuel ItKonen (1891-1968), AND THE Sámi Collections at the National Museum of Finland}

With his research, numerous publications, collections gathered, and influences on the Sámi representations, Itkonen became one of the most prominent figures in the history of Lappology in Finland. This was also reflected in his long-lasting career at the National Board of Antiquities. Considering the Sámi collections in the National Museum of Finland, the role of Itkonen cannot be overestimated, as Nina Puurunen suggests (Puurunen 2002:33).

In some part of the exhibitions, the Skolt Sámi were subjected to the almost compulsory reindeer equipage or the representation of reindeer herding, which later changed into something of a stereotype for all Sámi culture. ${ }^{7}$ This does not, however, entail that nomadic reindeer herding would have been (over) emphasized in the exhibitions, because wild deer/reindeer have been a very important quarry, and later herding, animal also for Skolt Sámi as well as for the Inari Sámi. Some of the Skolt Sámi were still seminomadic into the 1920s and 1930s. For many others, reindeer were an important part of the diverse economy, and they also carried strong symbolic meaning. Considering reindeer as a stereotype in Sámi representations is always a problematic generalization, since the stereotype is more in the way one looks at something, rather than the object itself. There can be "frozen" representations of the reindeer and the Sámi, as well accurate and creative representations.

Many of Itkonen's theoretical starting points are outdated, and he can be criticized for his conclusions and opinions related to the ideas of his time, such as the understanding of Sámi as "a less developed race" or culture without possibilities to survive in the modern world (Lehtola 2017). Our study shows that these theoretical ideas directed his collecting practices to some extent. In view of collecting items of a supposedly vanishing culture, he collected many objects that were already going out of use, in most cases, due to the influence of colonialism and neighboring cultures and new influences. Itkonen was not interested in the changes underway in Sámi culture, but rather focused on features he considered to be "genuine", "original" and "pure". For this reason, he also concentrated on objects that especially distinguished the Skolts from the other Sámi peoples. Thus, the large collection of Skolt Sámi culture can partly be explained by the understanding of Itkonen's time, that is, that the Skolt Sámi represented most archaic and original form of Sámi culture.

\section{Notes}

1. One of the oldest and largest scientific societies in Finland. It was established in 1883 and it aims to support Finno-Ugric languages and the research related to the culture, ethnology, folklore and prehistory of these peoples (Finno-Ugrian Society)

2. From the trip in 1926, for instance, we can read from the museum diaries that he purchased

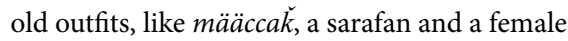
hat from Uljaana and Naska Moshnikoff. From Kiureli Moshnikoff, he bought a small wooden meat vessel and a traveling Sámi coffin, from Huotari Moshnikoff a root vessel, from the Sverloff family two bark boxes and from Inari Sámi Juhan Matti Saijets a small Sámi coffin, bark box and shoelaces. The information is much more precise than from the journey to Suonikylä and Nuortijärvi in 1913, for instance, when he only writes that about half of the population was still in the winter village. Thus, we can only guess which families sold him objects (Itkonen 1991:93-94, SU 4922).

3. Nyeri Piäkkä was named after his homestead in the village of Nellim, located by a strait in Lake Inari, a nyere in Inari Sámi language. 
4. At the Museum of the Student' Association (founded 1876) which became later 1893 a part of State History Museum/Finnish National Museum, the mannequins was made by artist $\mathrm{K}$. A. Söderman in Stockholm, Finnish artists Carl Wilhelm "Ville" Vallgren and Carl Lenngren (see Th. Schwindt \& U. T. Sirelius. Suomen ylioppilasosakuntain kansatieteellinen museo vv 1876-1893, SMYA XXXIII (1922), page 8-9. We thank the anonymous referee for this tip.

5. This was the way that all the mannequins were made to the Finno-Ugric exhibition. They were supposed to look as racially real as possible.

6. Contrary to the old exhibition, the vitrines now had signboards and there were a lot less objects, while the thematic order made the exhibition a lot easier to handle. The exhibition and guidebooks (1951 and 1957) completed one another, but the guidebook worked also without the exhibitions. In addition, a small leaflet Pictures from the collections (Suomen Kansallismuseo 1954:59-60) presented examples of skillful ornaments and a harnessed reindeer from Enontekiö.

7. It would be fruitful to compare the 1923 exhibition and its followers with the Swedish Arthur Hazelius Scandic Ethnographic Museum (opened 1873) which had an exterior diorama of Samis, shown also at the Paris world exhibition 1878. The museum became later Nordic Museum (Swe. Nordiska Museet), where the Sami exhibition was rebuilt by Ernst Manker, opened 1947, and again rebuilt in the 1970s.

\section{REFERENCES}

\section{Archival sources}

National Archive of Finland (Kansallisarkisto, KA)

Collection of T. I. Itkonen (T. I. Itkosen kokoelma, TIIA)

Finnish Heritage Agency's Archive (Museovirasto, MV)

Manuscript archive of ethnography (Kansatieteen käsikirjoitusarkisto, KTKKA):
982: Itkonen, Toivo Immanuel: On the Skolt Sami buildings [Koltanlappalaisten rakennuksista].1913.

983: Itkonen, Toivo Immanuel: Texts on living habits of the Lapps [Kirjoitelmia lappalaisten elintavoista I-II]. 1913.

984: Itkonen, Toivo Immanuel: Reindeer herding among the Lapps of Enontekiö [Enontekiönlappalaisten poronhoito]. 1916.

987-1006: Paulaharju, Samuli: Collections from Inari and Kola Laplands from the year 1914 [Keräelmät Inarin ja Kuolan Lapista vuodelta 1914].

\section{Photo archive (Kuva-arkisto)}

Kansallismuseo. Finno-Ugrian Exhibitions I and II [SUK-Näyttely I ja II] VIII2: 5A4.

Kansallismuseo. Exhibitions in Ateneum 1894, 1903, and at the National Museum 1908- 1955 [Näyttelyt Ateneumissa 1894, 1903, KM:ssa]. VIII0: 17D4.

Section of the National Museum [Suomen Kansallismuseo -osasto (SKM)]:

Main catalogue of the Finnish ethnographic objectcollections [Kotimaisten kansatieteellisten esinekokoelmien pääluettelo]

Thematic file the Sami object-collections [Saamelaisten esinekokoelmien aiheenmukainen kortisto]

Diaries of the Finno-Ugric collections [Suomalaisugrilaisten kokoelmien diaarikirja]

Main catalogue of the Finno-Ugric collections [Suomalais-ugrilaisten kokoelmien päluettelo]

Verifications, Finno-Ugric collections [Suomalaisugrilaisten kokoelmien verifikaatit]:

Ilmari Itkonen 1910 to the leader of the National Museum 14.5.1910. Suomen Kansallismuseo.

Lagercranz, Eliel 1919 to U.T. Sirelius. Suomen Kansallismuseo.

Lagercranz, Eliel 1931. Account of the collection of ethnographic objects in Lapland by Eliel Lagercrantz 1919-1920 [Kertomus Eliel Lagercranzin kansatieteellisten esineiden 


\section{SKolt SÁmi Heritage, ToIvo Immanuel ItKonen (1891-1968), AND the Sámi Collections at the National Museum of Finland}

keräilystä vuosina 1919-1920 Lapissa]. Suomen Kansallismuseo.

\section{Nordiska museet}

Huvudliggaren för föremålaccessioner.

The archive of The Finno-Ugrian Society (SuomalaisUgrilaisen Seuran arkisto, SUSA)

The minutes of the board of the The FinnoUgrian Society [Suomalais-Ugrilaisen Seuran johtokunnan pöytäkirjat] 1912-1914

\section{Unpublished sources}

Feodoroff, Pauliina. Oral information 12 November 2018

Feodoroff, Pauliina. Correspondence 21 January 2019 Guttorm, Anni. Email-correspondence 2 May 2019 Havas, Honna. Pers. com. 26 April 2019

\section{Internet resources}

Bååstede. https://norskfolkemuseum.no/en/ ba\%C3\%A5stede

Finno-Ugrian Society. https://www.sgr.fi

Ä'vv 2018. http://www.skoltesamiskmuseum.no/

\section{Literature}

Aarekol, Lena 2016. “Samuli Paulaharju.” In MatsOlov Olsson (ed.). Encyclopedia of the Barents Region, Volume II. Oslo: Pax Forlag, 149-150.

Harlin, Eeva-Kristiina 2019. "Returning home. The different ontologies of the Sámi collections." In Thomas Hylland-Eriksen, S. Valkonen \& J. Valkonen (eds.). Knowing from the Indigenous North. Sámi Approaches to History, Politics and Belonging. London: Routledge, 47-66.

Härö, Mikko 1984. Suomen muinaismuistohallinto ja antikvaarinen tutkimus. Muinaistieteellinen toimikunta 1884-1917. [Formation of the administration and research of antiquities in Finland.] Helsinki: Museovirasto.

Itkonen, T. (Terho) 1991. Saatasanat. [Introduction.] T. I. Itkonen: Lapin-matkani. Helsinki: WSOY, 9-19. Itkonen, Toivo Immanuel 1941. Lappalaisten leikit ja ajanvietot. [Plays and hobbies of the Lapps.]
Itkonen, Toivo Immanuel 1948. Suomen lappalaiset vuoteen 1945 I-II. [Lapps in Finland.] Helsinki: WSOY.

Itkonen, T. I. (Toivo Immanuel) 1991. Lapin-matkani. [My travels in Lapland.] Ed. by Terho Itkonen. Helsinki: WSOY.

Lehtola, Veli-Pekka 2012. Saamelaiset suomalaiset kohtaamisia 1896-1953. [Sámi-Finnish Relations in 1896-1953.] Helsinki: SKS.

Lehtola, Veli-Pekka 2015. "Second world war as a trigger for transcultural changes among Sámi people in Finland." Acta Borealia 32:2, 125-147.

Lehtola, Veli-Pekka 2016. “Itkonen, T. I." In Mats-Olov Olsson (ed.). Encyclopedia of The Barents Region. Volume I. Oslo: Pax forlag, 328-329.

Lehtola, Veli-Pekka 2017. "Vanishing Lapps, progress in action. Finnish lappology and representations of the Sámi in publicity in the early 20th century." Arctic and North 27, 83-102.

Lehtola, Veli-Pekka 2018a. "Our histories in the photographs of the others. Sámi approaches to visual materials in archives." Journal of Aesthetics \& Culture 10:4, article 1510647, https://doi.org/10 .1080/20004214.2018.1510647

Lehtola, Veli-Pekka 2018b. "'The soul should have been brought along.' The settlement of Skolt Sami to Inari in 1945-1949." Journal of Northern Studies 12:1, 53-72.

Lonetree, Amy 2012. Decolonizing Museums: Representing Native America in National and Tribal Museums. Chapel Hill: The University of North Carolina Press.

Magnani, Natalia 2018. Making Indigenous Future: Land, Memory, and "Silent Knowledge" in a Skolt Sámi Community. Dissertation. Oxford: University of Oxford.

Mathisen, Silje Oppdahl 2017. "Still standing. On the use of dioramas and mannequins in Sámi exhibitions." Nordisk Museologi 1, 58-72.

Olsen, Bjørnar 2000. "Bilder fra fortida? 
Representasjoner av samisk kultur i samiske museer." Nordisk Museologi 2, 13-30.

Potinkara, Nika 2015. Etnisyyden rakentuminen kahden saamelaismuseon perusnäyttelyissä. [The formation of ethnicity in the main exhibitions of two Sámi museums.] Dissertation. Jyväskylä: University of Jyväskylä.

Puurunen, Nina 2002. "Saamelaisuus

Kansallismuseossa. Suomen kansallismuseon saamelaisten esinekokoelmien muodostuminen, karttuminen ja analyysi." [Sáminess in the National Museum of Finland. The Formation, Accumulation and Analysis of Sámi Collections in the National Museum of Finland.] Master's thesis. Helsinki: University of Helsinki.

Schvindt, Theodor \& Sirelius, U.T. 1922. "Suomen ylioppilasosakuntain Kansatieteellinen museo vv. 1876-1893." Suomen Muinaismuistoyhdistyksen aikakauskirja XXXIII, 3-22.

Sihvo, Pirkko 1977. "Kansallismuseon kotimaisten kansatieteellisten kokoelmien syntyvaiheita." [Development of first ethnographic collections at the National Museum of Finland.] Ethnologia Fennica 1-2, 47-61.

Sihvo, Pirkko 2001. Palava mieli. Kansatieteellinen arkeologi Theodor Schvindt. [Ethnographic archeologist Theodor Schvindt.] Jyväskylä: Gummerus.

Silvén, Eva 2014: “Constructing a Sami Cultural Heritage. Essentialism and Emancipation." Ethnologia Scandinavica 44, 59-74.

Sirelius, U.T. 1916. "Suomen Kansallismuseo, sen synty, kehitys ja nykyiset laitokset. Historiallinen katsaus." [Formation, development and contemporary activities of the National Museum of Finland.] Historiallinen aikakauskirja 1, $1-34$.

Talvio, Tuukka 1993. H. F. Antell ja Antellin valtuuskunta. Helsinki: Museovirasto.

Talvio, Tuukka 2016. Suomen Kansallismuseo. Ikkuna menneeseen ja tulevaan. [Past and present of the National Museum of Finland.] Helsinki: Museovirasto.

Varjola, Pirjo 1982. "Suomen kansallismuseon yleisetnografinen kokoelma." [The Ethnografic collection in the National Museum of Finland.] Suomen Museo 1981, 51-86.

Varjola, Pirjo 1990. The Etholen Collection. National Board of Antiquities of Finland. Helsinki: National Board of Antiquities.

Webb, Sharon 2006: "Making Museums, Making People: the Representation of the Sámi through Material Culture." Public Archaeology 5:3, 167-183.

Eeva-Kristiina Harlin, Master of Arts eeva-kristiina.harlin@gmail.com

\section{Giellagas Institute for Saami Studies \\ University of Oulu \\ PO Box 1000, 90014 University of Oulu}

Veli-Pekka Lehtola, Ph.D., Professor of Saami cultural studies veli-pekka.lehtola@oulu.fi

Giellagas Institute for Saami Studies University of Oulu PO Box 1000, 90014 University of Oulu 